\title{
Testing for Pro-Poorness of Growth through the Tax System: The Mexican Case
}

\author{
Luis Huesca ${ }^{1, *}$ and Linda Llamas ${ }^{2}$ \\ ${ }^{1}$ Department of Economics at Centro de Investigación en Alimentación y Desarrollo (CIAD), Mexico and \\ CIRPÉE Research Fellow, Université Laval, Canada \\ ${ }^{2}$ Universidad Estatal de Sonora (UES) and PhD Student at CIAD, Department of Economics, Mexico
}

\begin{abstract}
This research provides a detailed examination of the redistributive effect achieved by the tax system including total taxes and cash transfers targeting the contributors and households in the period 2002-2008-2014 for the Mexican regions and the country. We measure the impact on income growth through the tax system according to each fiscal rules for the corresponding years using pre and post fiscal conditions. We answer the next question: considering the economic growth on per capita incomes in the Mexican states, will the impact of the Mexican tax system improve income distribution? That is, by all means pro-poor? Our methodology allows to detect if taxes and benefits can really induce an improvement of income growth on the regions captured by its wellbeing and economic growth conditions. We outlined relevant theoretical issues on public fiscal policies concerning this work and lastly, we proceed with an empirical application to develop some recommendations for the Mexican fiscal policy system.
\end{abstract}

Keywords: Fiscal policy, pro-poor regional growth, redistribution, progressivity.

\section{INTRODUCTION}

The impact of fiscal policy not only to collect revenues but also to allocate transfers for the population have been an important issue in the social policy agenda among the countries; however, it is difficult to quantify the action of the tax system as a whole through social programs and if these actions can induce growth of incomes to the low incomes groups. The Andean countries considered as the poorest in the Latin American region, such as Peru, Ecuador and Bolivia have paradoxically performed well as a result of its growth and the effect of policies applied, inducing a higher relative growth on incomes for the poorest population (Araar 2012).

The aim of this paper goes to apply both, at the theoretical and empirical level the pro-poor methodology with the redistributive effects achieved through the tax system (that is, ex-ante vs ex-post situation) including the tax burden and cash transfers on the whole distribution of households in Mexico, for the years 2002, 2008 and 2014. Our motivation is to analyze pro-poor growth on pre and post-fiscal incomes linked to the tax system using taxes and benefits, with taxes on personal income and for consumption as well as special taxes on specific goods in the country and its regions.

*Address correspondence to this author at the Department of Economics at Centro de Investigación en Alimentación y Desarrollo (CIAD) and CIRPÉE Research Fellow, Hermosillo, Sonora, Mexico; Tel: 52-662-289-2400 ext. 371; E-mail: Ihuesca@ciad.mx
In order to do so, we look to contribute evaluating unambiguously if, the fiscal conditions are met to be pro-poor in these years, benefiting the population and mostly, the low income groups of the distribution. If this is not the case, we will be able to shed light in some elements to give policy recommendations, allowing the fiscal system to be a tool with a better way of collecting taxes as well as for improving income redistribution on households and tax-payers.

In order to obtain the growth values of per capita GDP for the Mexican states, for the empirical application we use the data bases of Mexican states GDP and the Population Statistics by Mexican federal entity presented in German-Soto (2005) and (2014) respectively, then we combine this information with microdata from Encuesta Nacional de Ingresos y Gastos de los Hogares (ENIGH for its initials in Spanish).

The order of the paper is presented as follows. Second section offers a literature review on the impact of redistribution as a result from various fiscal systems, incidence of taxes and its effects coming from policies of pro-poor type; third section explains the theoretical approach and it derives the mathematical method, describing the construction of the fiscal data; fourth section shows the empirical application which evaluates redistribution of the fiscal system in Mexico and the transfers as well; finally, fifth section ends with some reflections to improve the fiscal system in Mexico according to its heterogeneous states and its corresponding regions. 


\section{TAX-BENEFIT SYSTEM AND ITS LINK WITH} PRO-POORNESS

The success or failure in the implementation of fiscal policies have been evaluated over time to fulfill its purpose, such as funding public expenditure and in some cases, for redistribution. Amongst the most important programs we find the pensions, social security, housing and health services as relevant for redistribution. Fiscal policy then, can exert regionally redistributive impact to the extent that it collects revenues for social spending and allocates resources through transfer programs, as suggested by Buchanan and Musgrave (2001:68).

\section{a. An Overview of the International Tax-Benefit Systems}

Fiscal policy recommendations up to date for developed and middle-income countries (such as Mexico, Uruguay, Chile, Argentina and Brazil) have focused on developing a tax structure to increase revenues mainly, through indirect taxes (Bird 1995; Bird and Gendron 2011). However, this recommendation had led to very different scenarios, that is, an efficient tax system must consider the redistributive action as a whole to treat different ranks of taxpayers. To be able to increase revenues and to address inequality the government must consider that the tax structure should be modified. (Musgrave 1990).

From the seminal study of Pechman and Okner (1974) in the United States, there have been a significant number of research related to the measurement of progressivity, but none using the propoor issues. Pechman and Okner presents a proportional tax system as a result of neutrality combining progressive and regressive taxes. This topic has been addressed in developed and for some economies in transition and developing countries as well. $^{1}$

Bibi and Duclos (2010) study the dominance of poverty through the tax system for five developed countries: Sweden, United Kingdom, Canada, US and Germany. This research show that USA and Canada presented the least impact on poverty levels from market income (which approximates the measuring of gross income) than Sweden, Germany or the UK.

\footnotetext{
'See the studies of Davidson and Duclos (1997) for the Canadian case, Wagstaff and Van Doorslaer (2001) for a group of five countries of the OECD, Claus, Martinez-Vazquez, and Vulovic (2013) in Asia; Lustig, Pessino, and Scott (2014), Scott (2014) and Huesca and Araar (2016) in the Mexican case.
}

When social transfers are added to market income, the net impact on reduction of poverty levels improves for Sweden, Germany and the UK. Moreover, the authors illustrate how the redistributive effect has a greater impact in the reduction on poverty for Sweden; while in the UK it dominates the other countries in terms of social transfers, but Canada emerges as the country with the greatest success in taxation to prevent a sudden increase of poverty. Furthermore, in Canada and Sweden social transfers and taxes have one of the best results in reducing poverty among this pool of countries.

In Latin America and six of their countries (Peru, Bolivia, Mexico, Brazil, Argentina and Uruguay) Lustig, Pessino, and Scott (2014) estimate progressivity and regressivity from the tax-benefit systems and its corresponding impact on poverty. Bolivia, Mexico and Peru presented the lowest impact on poverty reduction, while Argentina, Uruguay and Brazil showed the largest reductions, where these later are the countries with better effect of redistribution in the first decade of the millennium. Meanwhile, Scott (2014) presents an assessment of the redistributive impact of the Mexican system comparing the years 2008 and 2010, and finds an increase of progressivity in 2010 . The previous research only inquired about the progressive and regressive taxation systems, but there is nothing clear about the effects of pro-poor growth on families and individuals.

\section{b. Studies Focusing on Pro-Poor Tax Systems}

Duclos (2009) declares axiomatically the pro-poor concept to measure the quality of growth for an economy. In this regard, only two articles have used information from Mexico, but following an axiomatic approach (Duclos, Makdissi, and Araar 2014; Araar, et al. 2009).

The research from Araar, et al. (2009) defines the various concepts of pro-poor and supports the use of many methods that can generate robust results, over a wide ranges of poverty lines. Using Mexican surveys for 1992, 1998 and 2004 they show that the evidence for growth was anti-poor between 1992 and 1998, of type absolutely pro-poor between 1998 and 2004 and between 1992 and 2004, and relative pro-poor between 1992 and 2004 as well as between 1998 and 2004.

Recently, Duclos, Makdissi, and Araar (2014) computes the effect of indirect consumption tax reforms 
with changes in the Value Added Tax (VAT) in Mexico. Findings show that considering reductions in the rate of taxation for specific inferior products, those changes will never be of absolute pro-poor type; while reductions in VAT rates for necessary goods such as food and energy are checked to be of relative pro-poor type. In addition, it is indicated how as VAT reform were neutral in revenues for this exercise, a reform that decreases rates on taxes for necessary goods but increases those for transport services would be of propoor in both sense, relative and absolute terms.

\section{THEORETICAL REFERENCE FRAMEWORK}

In this section, we present the theoretical framework used in this study to analyze the following points in Mexico:

Assess the quality of regional pro-poorness in the distribution of income induced by the taxbenefit system.

Develop a regional combination of Mexican states according to its economic growth and wellbeing levels.

We introduce the theoretical framework, then we test and measure the quality impact of the tax system as a result of taxation and transfers in the households. We proceed with the development of a basic model that follows the importance of using pro-poor curves to foresee, if the redistribution that produces the tax system is in favor not just for the lowest incomes, but also for all the distribution in the years 2002, 2008 and 2014. Our hypothesis for the country and regions establishes that the pro-poor impact of the net tax balance (taxes minus benefits) on household wellbeing could have increased on average for the lowest percentiles during this period. We considered that initial years have the lowest impact on income growth for the entire population.

\section{a. Notation and Methodological Approach}

First, we start by explaining for two moments how the connection between pro-poorness and growth linked to a tax system is displayed on pre and post fiscal incomes (gross and net incomes, onwards). The question is, how could be evaluated this relationship? we begin by using the assumption that gross incomes are an initial vector of non-negative monetary values at time 1 with size of $n_{1}$ as $y_{1}=\left(y_{1}^{1}, y_{2}^{1}, \ldots, y_{n 1}^{1}\right) \in \mathbb{R}_{+}^{n 1}$, and net incomes a final vector of incomes values at time 2 with population size $n_{2}$ as $y_{2}=\left(y_{1}^{2}, y_{2}^{2}, \ldots, y_{n 2}^{2}\right) \in \mathbb{R}_{+}^{n 2}$, where $y_{2}=N \geq y_{1}=X$ as a priority condition to reveal that the tax system has a pro-poor effect over any cumulative distribution function $F(X, N)$.

Following Araar (2012) and Duclos (2009) we want to determine whether a movement from $y_{1}$ to $y_{2}$ is propoor, where $y_{1 j}=X_{j}$ and $y_{2 j}=N_{j}$ as gross and net incomes consider the effect from taxes and benefits respectively, located in a region $j$ with a level of income $X_{j}, N_{j}$ using a factor $(1+g)$ as growth $g$ for incomes at time 2 .

We assume that both nominal and real incomes in space of ex-ante and ex-post units are the same, departing from the reference prices as ex-ante. ${ }^{2}$ So we can assume that both $F(X j, a) \geq 0, F(N j, a) \geq 0$, for all $X j, N j>a$, where $a$ is a factor that refers to a norm of standard relative change in real income considering the net balance of taxes and benefits from the fiscal system, as:

$$
a=\frac{\partial \mu}{\partial\left(t_{i}-b_{i}\right)} d t_{i}-b_{i}=-N_{i}(q) d t_{i}-b_{i}
$$

where $a$ expresses the relative change with respect to real income, $\mu$ is the average income, and the average impact of taxes and transfers is captured by $d\left(t_{i}-b_{i}\right)$, which is weighted by the purchasing power of net income denoted as $N_{i}(q)$ in expression (1).

There are two pro-poor judgements: absolute and relative. The first refers to a situation where incomes grow by an absolute amount that is no less than some norm, and the second takes into account mean income growth and indicates if the increase of the incomes are greater to this value, such as variable $a$ in equation (1) for instance.

First, as we do not want to focus only on poverty groups, we check if the distributional change on incomes is first order relatively pro-poor $(s=1)$ by comparing the ratio of the quantiles to growth in mean income, and for all percentiles of population as follows:

$$
\Delta Q_{X j, N j}(p)-\mu d F\left(N_{j}\right) / \mu d F\left(X_{j}\right)
$$

Where $F(\bullet)$ is the cumulative distribution function of the corresponding net and gross incomes for each $j$

\footnotetext{
${ }^{2}$ It is useful here to think that both $X, N$ and the norm $a$ are defined at constant prices or real variables, as suggested by Duclos, Makdissi, and Araar (2014:92), so that we cannot consider the poverty line $z$ will vary with fiscal rules or over time.
} 
region, $\Delta Q_{X j, N j}(p)$ is the ratio of the quantile function for each unit of income in the distribution of households at rank $p$ in the distribution.

A distributional change is second order relatively pro-poor by using Generalized Lorenz curves comparing the growth rates in the cumulative incomes $\left(X_{i j}\right.$ and $N_{i j}$ ) up to rank $p$ with growth rates, and can be defined as follows:

$G L_{i j}(p)=\int_{0}^{p} Q_{i j}(q) d q$

Where $G L$ stands for the Generalized Lorenz curve as a sufficient condition for checking $s=2$ as second order condition relative pro-poorness, and consecutively a distributional change will be $s=2$ for $R$-pro-poor if for all $p \in\left[0, F_{2}\left((1+g) a^{+}\right)\right]$with growth rates in the cumulative incomes with shares $p$ of the lowest incomes, if and only if expression (4) is confirmed:

$\Delta(p)=\frac{G L_{2 i j}(p)}{G L_{1 i j}(p)} \geq 1+g$.

Expression (4) compares the growth rates for all the quantiles with those growth rates to $g$, when $1+g$ is equal to the ratio of mean income in the general distribution. $^{3}$

\section{b. Pro-Poor Properties}

Essentially, it can be out of reach whether the functioning of the fiscal system reduces or increases the absolute levels of regional poverty in this research; however, what it can be done is to qualify if this condition can be considered as pro-poor or just good for the entire population. This argument of measurement requires distinguishing between their relative and absolute level. Both, absolute and relative pro-poor judgments also includes primal and dual approaches to identify the distributional change over a wide range of poverty lines and the distributional change over growth in mean income, respectively (Duclos and Araar 2006). For the purpose of this paper, we examine dual approaches with relative pro-poor judgments.

\footnotetext{
${ }^{3}$ Expression (2) and (4) arises from the dual relative approach considering first and second order conditions. Both have been estimated in this paper using DASP v2.3 software programmed by Araar and Duclos (2013).
}

Both definitions proof again the difference between the two approaches. ${ }^{4}$ Meanwhile, the standard norm $a$ from expression (1) explains the numerical change operated on average real incomes of population. Then, the norm $a$ implicitly exposes the definition of type absolute A-pro-poor, linking us to an absolute reduction of inequality; and the norm $g$ for the definition of type relative $R$-pro-poor with regards to the relative growth on real incomes in the population. Also, for the potential impact on the reduction on relative inequality in the final distribution, a theorem can be stated as follows:

Theorem $1 A$ marginal reduction on the tax $t_{i j}$ or increase on the benefit $b_{i j}$ is $\eta$-pro-poor $(\eta \in\{R\})$ for all the quintiles $Q \in[0,1]$ if and only if

$X_{i j}^{\eta: s}(Q) \geq 0, \forall Q \in[0,1]$.

Where $s$ stands for $s=1$ as first order condition (explained in expression (2)) and, $s=2$ for second order condition using the Generalized Lorenz criterion explained in expression (4).

Corollary 1 Regardless of the value taking the order $s$ and the participation from $g$ (growth) on the $Q$-quantiles given a tax-benefit system, we will get in any household $i$ and for each region $j$ :

1. an increase in $t_{i j}$ and $b_{i j}$ is not R-pro-poor if reduces the share of the lowest quintiles in the distribution if and only if $d\left(t_{i j}-b_{i j}\right)>0$;

2. an increase in $t_{i j}$ and $b_{i j}$ will always be R-propoor if increases the share of the lowest quintiles in the distribution if and only if $d\left(t_{i j}-b_{i j}\right)<0$;

3. an increase in $t_{i j}$ and a reduction in $b_{i j}$ is not $R$ pro-poor if reduces the share of the lowest quintiles in the distribution if and only if $d\left(t_{i j}-b_{i j}\right)>0$;

4. an increase in $b_{i j}$ and a reduction in $t_{i j}$ will always be R-pro-poor if increases the share of

\footnotetext{
${ }^{4}$ While $R$-pro-poor normalize incomes as a ratio $1+g$ giving relative rates of growth, the A-pro-poor uses dispersion of incomes with regards to a change on distribution in absolute units of income. These approaches are totally consistent with Kakwani and Pernia (2000:3) which states how to "Promote pro-poor growth requires a strategy that is deliberately biased in favor of the poor, in such a way that it is precisely the poor who benefited proportionately more than the rich." So we see that it is vital to quantify the extent to which the lowest income quantiles participate in that growth as well as changes in distribution.
} 
the lowest quintiles in the distribution if and only if $d\left(t_{i j}-b_{i j}\right)<0$.

\section{EMPIRICAL APPLICATION}

\section{a. Database of the Fiscal System}

For the empirical exercise, we unified a series of the survey Encuesta Nacional de Ingresos y Gastos de los Hogares (ENIGH) carried out by Instituto Nacional de Estadística (INEGI 2015a) considering the years 2002, 2008 and 2014 and deflated incomes using a CPI with 2012 as a reference year; the surveys were carried out in the month of August. Based on the information provided by its microdata and to make it comparable to the official reports, we proceed to build the distribution according to the CONEVAL equivalence scale and following both direct and indirect identification methods. ${ }^{5}$ See Table A1 in Appendix to see the taxes and benefits of income components in the construction of the fiscal system.

There is a consensus on the relevance of using the individual as the main unit of distributive analysis and to ensure an accurate estimation of wellbeing for household members. Hence, the primary step is to assess the wellbeing of individuals and it must be done by adjusting the total household income by family size and composition. The simplest method is to use per capita income, that is, to divide the household income by the household size. In our case, we use the equivalence scale from CONEVAL (2009) to account for individual wellbeing. The adult equivalent scale is defined as follows: $[0-5]=0.7,[6-12]=0.74$, [13-18]= 0.71 , and $[19-65+]=0.99$. In this sense, we are comparing homogeneous units with regards to their basic needs. ${ }^{6}$

The surveys used accounts for a number of 17,129 observations in 2002; 28,849 in 2008 and 19,104 in 2014, representing $24.4,26.1$ and 31 millions of families for each year. The fiscal figures in the data explains the fiscal system simulated in this empirical application as follows:

$X=N+T+S S Q-B-P$

\footnotetext{
${ }^{5}$ See for instance Lustig, Pessino, and Scott (2014: 291).

${ }^{6}$ Note that this equivalence scale is also the national official scale estimated by CONEVAL (2009) in Teruel, Rubalcava, and Santana (2005). CONEVAL has followed Deaton (1998) approach in order to apply a flexible functional form using nonlinear regressions and sensibility analysis. They show that the cost of children between 0 and 5 years rises up to 0.77 percent, while that of children from 13 to 18 increases to 74 percent, even less than the cost for the previous group of 6 to 12 with 80 percentage units.
}

where $T$ represents the total tax-burden, $S S Q$ as the social security quotas of labor, $B$ as the total benefits as direct cash transfers given in the same surveys and $P$ as total pensions.

\section{b. Integration of the Mexican Regions}

In this section, we present a dynamic regionalization criteria for the Mexican states to capture the link between per capita Gross Domestic Product (GDP) growth and wellbeing level. First, we use the databases of Mexican states GDP by German-Soto (2005) and the Population Statistics by Mexican federal entity to obtain the growth values of per capita GDP for the Mexican states for the years 2002 and 2008, and to complete the series for the period of analysis, 2014 is obtained through the Sistema de Cuentas Nacionales, INEGI (2015b).

Second, we use the wellbeing poverty estimates from CONEVAL (2015) to be able of combining this poverty figures with that of per capita GDP growth levels in the country for each state. We generate the regions by separating those states that grew and those that did not, located in four areas and for each year. For a detailed description of the states and how these were grouped into the regions the reader can see Table $\mathbf{A} 2$ from the corresponding Appendix.

Figure 1 shows the scattergram in the four-area categorization with heterogeneous dispersion among the states, in which most of them spots at different locations from one year to another (only the states of Nuevo León and Distrito Federal remain in the same region number one for all the period). In region number two only Baja California is located in 2002, with low level of wellbeing and low growth, therefore we expect this will not bias the estimation for the number of observations in this year for this region. Sonora remains in region number two for the next years 2008 and 2014. In region number three the state of Morelos remain the same for the full period. Perhaps the most relevant feature is that region number four gathered during this period more states than its counterparts, from 12 states in 2002 to 21 in 2014.

Therefore, for all the years area one show the Mexican states with better wellbeing and those that grew; area two the states with better wellbeing but low GDP rate (below cero); while the areas three and four illustrate the Mexican states with lower wellbeing and both, low and higher per capita GDP growth, respectively. 

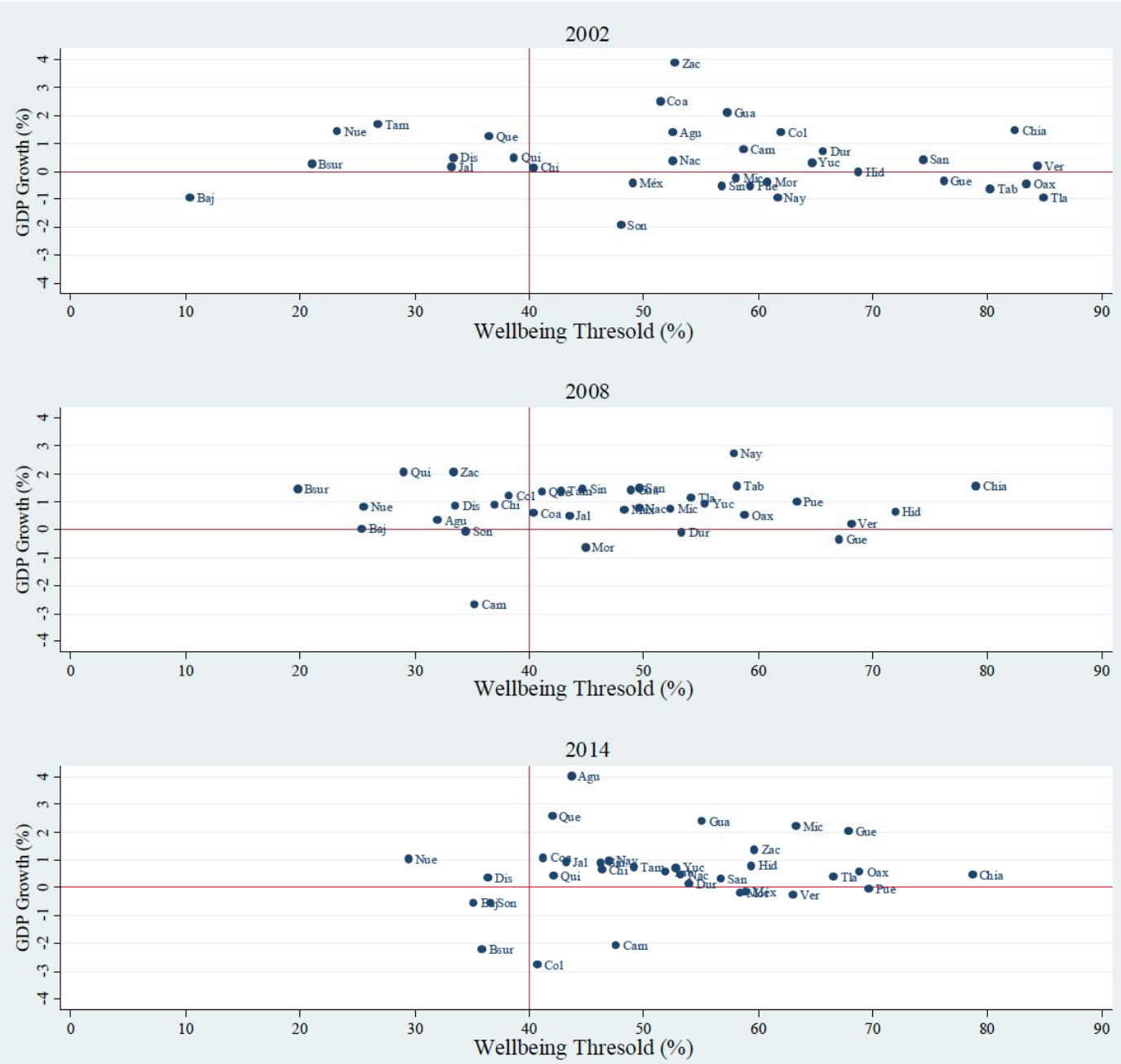

Source: Author's elaboration using ENIGH.

Figure 1: Scatterplot of growth and poverty in Mexico.

Source: Author's elaboration using ENIGH.

\section{c. Empirical Analysis of Data}

In order to capture the effect of the fiscal system in Mexico through the years, we illustrate a nonparametrical estimation of density curves for equivalent gross and net incomes. It can be seen in Graphs $\mathbf{1}$ and 2 density functions of gross and net incomes respectively. Two changes are worth pointing out. Firstly, the increase in the modes of the densities with greater impact in the year of 2008, which is a year prior to the Mexican crisis of 2009 where real GDP declined drastically in 7 points; secondly, 2008 emerges as the least affected year in per capita GDP growth, but in fiscal terms 2014 seemed to be in a better position, as long as the shape of its density function for net income remained flattened along the net income levels ( $g$ values were higher than economic growth in both, first and second order conditions). In general, real net income presented the lowest reduction on growth in 2008 (see Graph 2 and Table 1) for the country, which

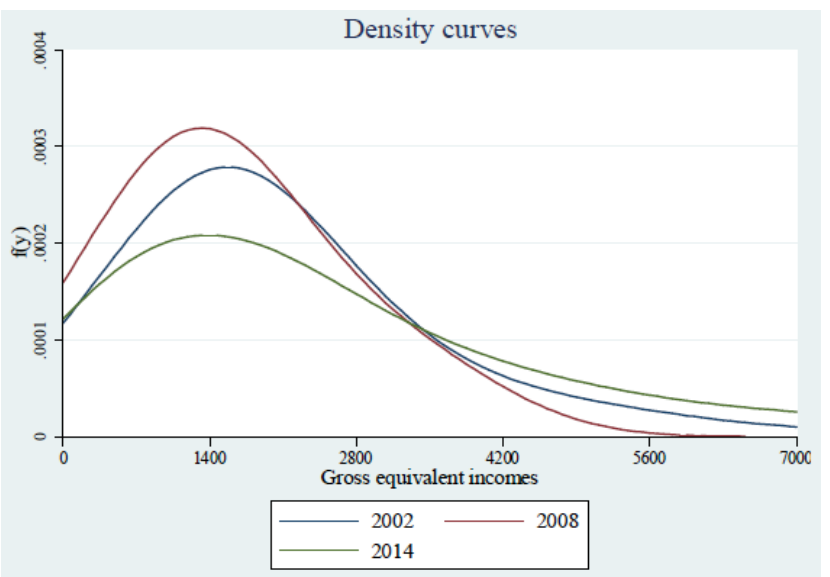

Graph 1: Density function of gross equivalent income: Mexico 2002-2008-2014.

Source: Author's elaboration. 
indicates that household wellbeing could have increased on average in 2008 as the possible better year with positive impact on equivalent income growth and the highest levels of wellbeing.

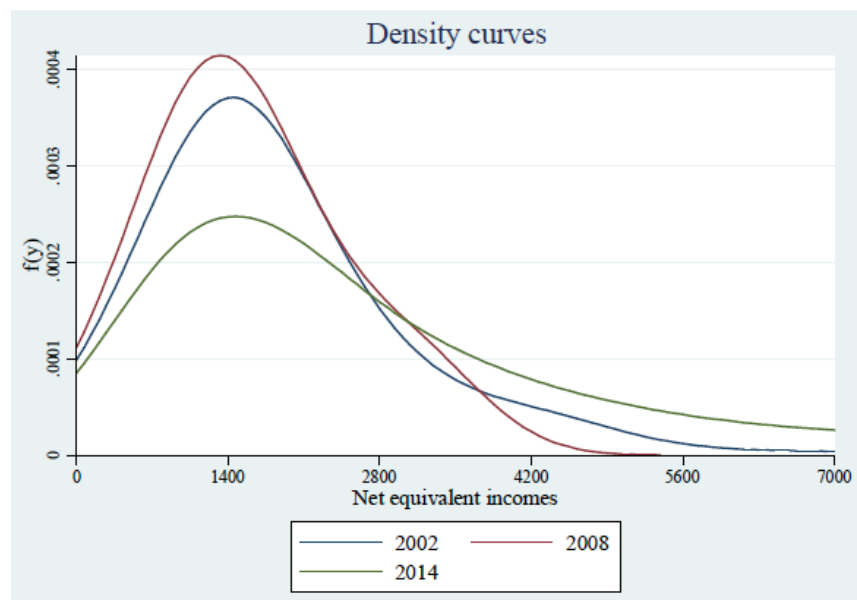

Graph 2: Density function of net equivalent income: Mexico 2002-2008-2014.

Source: Author's elaboration.

\section{d. R-Pro-Poor Application}

Now, we continue with the empirical application using the relative method and be able to test and judge during 2002, 2008 and 2014, if an improvement on mean incomes amongst the quintiles is present in the distributions. We have estimates of growth for $g$ values as well as for the means from $X$ and $N$ in Table 1. It can be seen how the fiscal system has evolved for each year in the country and its regions.

Using national accounts and the databases of German-Soto (2005 and 2014) to estimate per capita GDP growth in states of the country, we detect that real per capita GDP growth has been stagnant in the period, where the year 2002 registered 0.38 percent, 0.76 percent in 2008; and 2014 was 0.45 percent. It can be perceived how economic growth in Mexico remained low during 2002-2014, however, the region number four presented the higher positive rate of GDP growth for all the period, with a rate of $1.27,1.09$ and 1.15 percent for each year respectively. Notice that the better economic growth for these regions do not correspond to the greater wellbeing of the country, i.e. even though per capita GDP growth were higher in the periods for this region, a low level of wellbeing were persistent. For a detailed description of the states linked to the regions see Table $\mathbf{A} 2$ from the Appendix.

Using microdata from the corresponding surveys, for the $g$ values using second order condition (Lorenz criterion $s=2$ ), 2014 show to have consistently the

Table 1: Estimates of Per Capita Growth in Mexican Regions, for Income Distribution and Quintiles $\left(1^{\text {st }}-3^{\text {rd }}\right)$ 2002-20082014

\begin{tabular}{|c|c|c|c|c|c|c|c|c|}
\hline \multirow{2}{*}{ Year } & \multirow{2}{*}{$\begin{array}{c}\text { Country/ } \\
\text { Region }\end{array}$} & \multicolumn{2}{|c|}{$g^{S=1}(\%)$} & \multicolumn{2}{|c|}{$g^{S=2}(\%)$} & \multicolumn{2}{|c|}{$\mu$} & \multirow{2}{*}{$\begin{array}{c}\text { GDP } \\
\text { Growth }\end{array}$} \\
\hline & & $F(N)$ & $Q(0.3)$ & $F(N)$ & $Q(0.3)$ & $X_{i j}$ & $N_{i j}$ & \\
\hline \multirow{5}{*}{ ণิ } & Mexico & 0.1485 & 0.4210 & 0.3146 & 0.7978 & $3,501.73$ & 2,953.32 & 0.3800 \\
\hline & Region 1 & 0.1356 & 0.3103 & 0.2401 & 0.5012 & 4,323.20 & $3,527.84$ & 0.8171 \\
\hline & Region 2 & 0.0626 & 0.1608 & 0.1358 & 0.2849 & $5,113.45$ & $4,157.32$ & -0.9400 \\
\hline & Region 3 & 0.1517 & 0.4005 & 0.3845 & 0.9511 & $2,970.27$ & $2,554.97$ & -0.6133 \\
\hline & Region 4 & 0.2569 & 0.6789 & 1.3282 & 3.6722 & $3,368.91$ & $2,877.76$ & 1.2700 \\
\hline \multirow{5}{*}{ 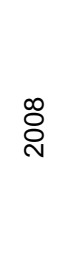 } & Mexico & 0.2165 & 0.6831 & 0.5639 & 1.6331 & $4,491.08$ & $4,203.82$ & 0.7600 \\
\hline & Region 1 & 0.2312 & 0.6332 & 0.6033 & 1.5759 & $4,719.44$ & $4,459.46$ & 1.0722 \\
\hline & Region 2 & 0.4820 & 1.3837 & 2.5283 & 7.2859 & $5,835.67$ & $5,417.84$ & -1.3750 \\
\hline & Region 3 & 0.3503 & 0.9797 & 1.0185 & 2.7424 & $4,096.73$ & $3,835.69$ & -0.3533 \\
\hline & Region 4 & 0.3076 & 0.8612 & 1.0043 & 2.7355 & $3,837.72$ & $3,621.05$ & 1.0978 \\
\hline \multirow{5}{*}{$\stackrel{+}{\circ}$} & Mexico & 0.4564 & 1.4538 & 0.8526 & 2.4878 & $3,750.65$ & $3,728.26$ & 0.4500 \\
\hline & Region 1 & 0.9847 & 2.7859 & 2.1354 & 5.9195 & $5,233.30$ & $5,202.90$ & 0.6750 \\
\hline & Region 2 & 0.4992 & 1.4495 & 0.8712 & 2.4114 & $5,120.76$ & $5,062.65$ & -1.1100 \\
\hline & Region 3 & 0.5097 & 1.4316 & 0.9556 & 2.5191 & $3,132.44$ & $3,160.21$ & -0.9217 \\
\hline & Region 4 & 0.4365 & 1.2090 & 0.8122 & 2.0195 & $3,648.27$ & $3,613.17$ & 1.1481 \\
\hline
\end{tabular}

Source: Author's elaboration using ENIGH and German-Soto (2005 \& 2014). 

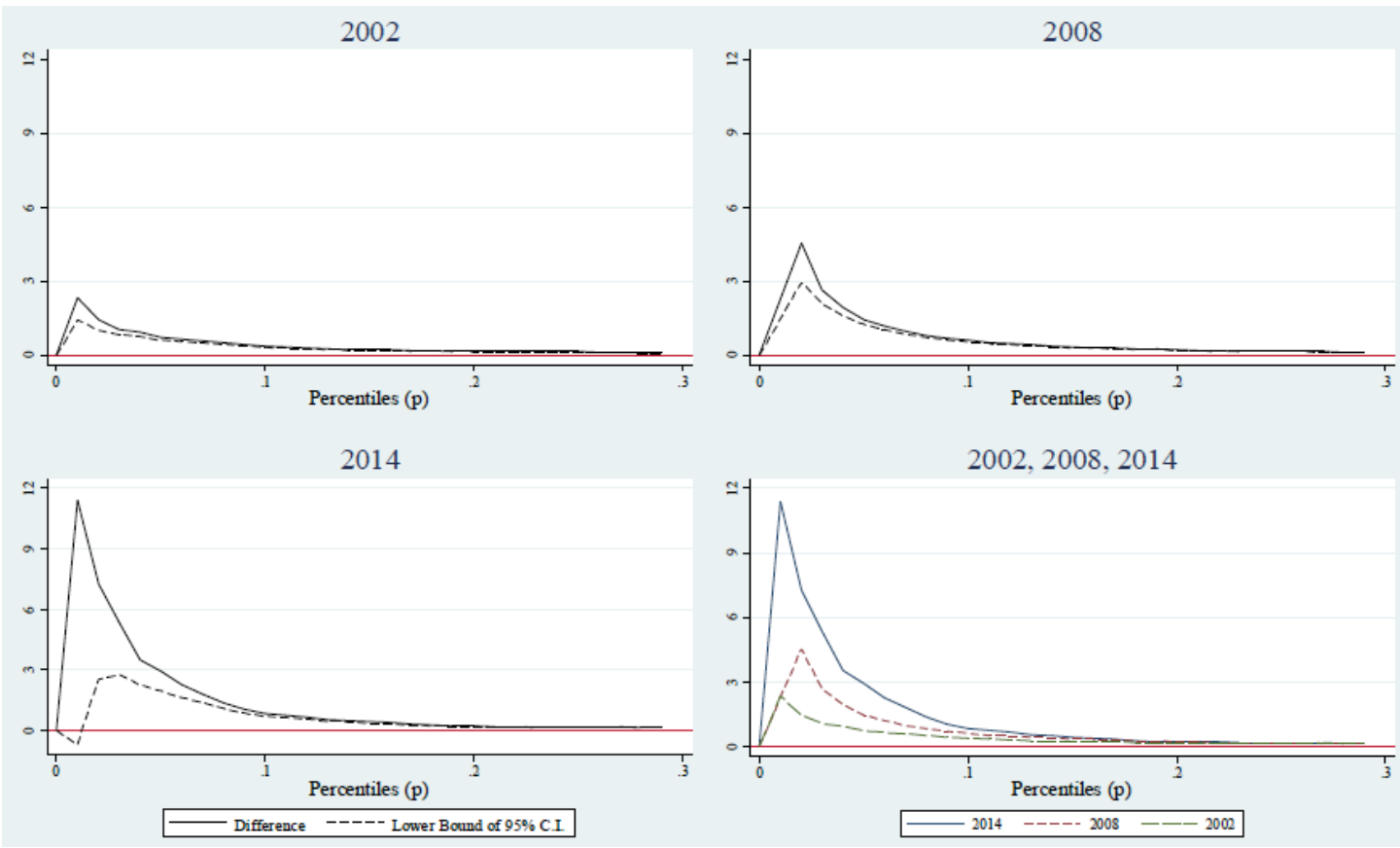

$2002,2008,2014$

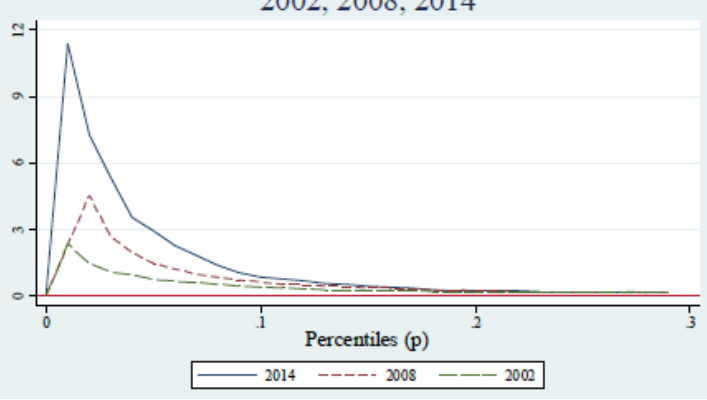

Figure 2: First order relative propoor curves in Mexico. Dual approach: (Q_2(p) /Q_1(p) - mu_2/mu_1). Source: Author's elaboration using ENIGH.
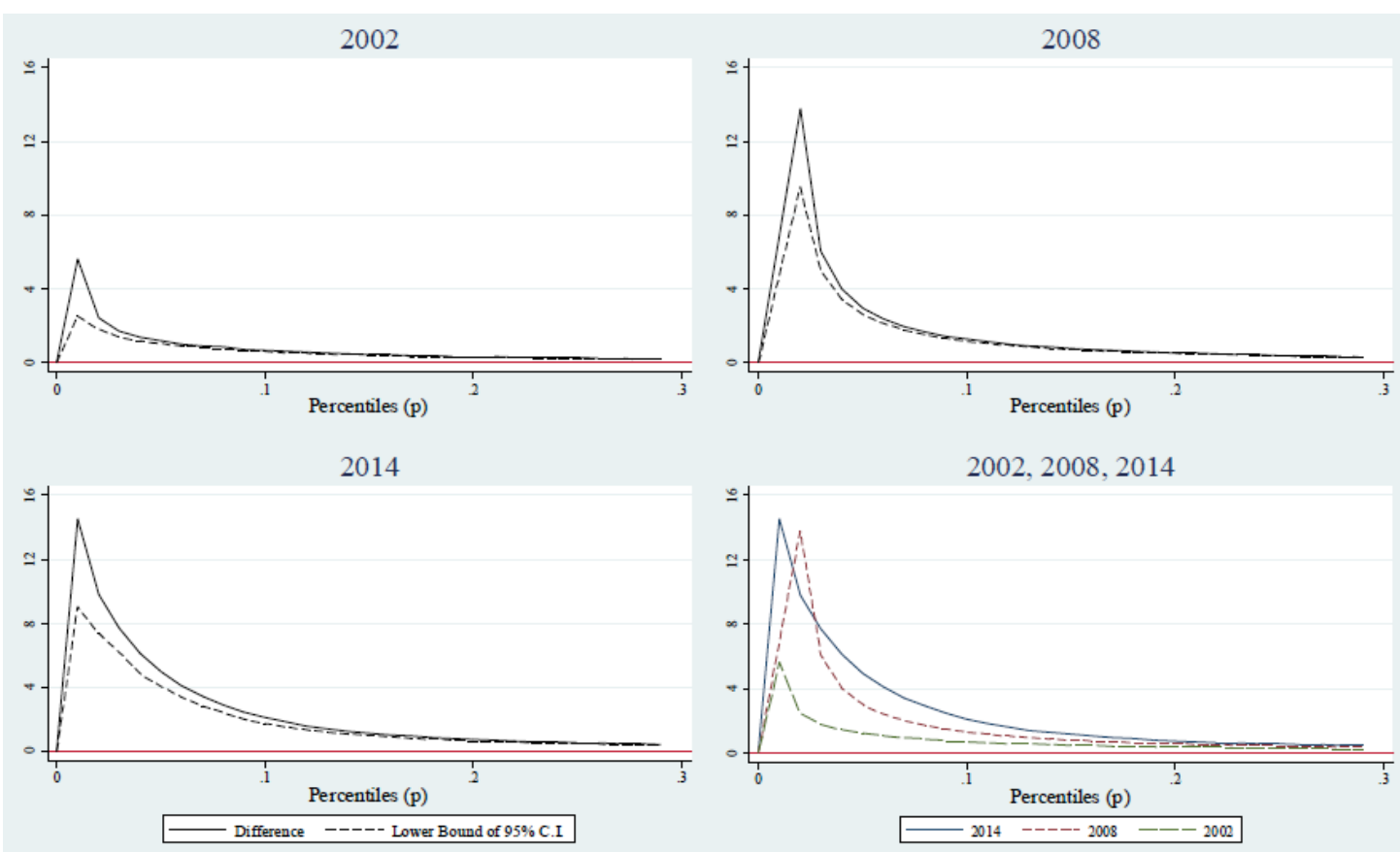

Figure 3: Second order relative propoor curves in Mexico. Dual approach: $\left(L \_2(p) / G L \_1(p)-m u \_2 / m u \_1\right)$.

Source: Author's elaboration using ENIGH.

more positive effect in the income growth for the quintiles 1, 2 and 3 for the country and in regions two, three and four, with values for $g$ of 2.41 percent, 2.52 and 2.02 percent correspondingly; while GDP growth was 0.45 percent in the same year for the country, and even a negative rate of GDP growth $(-1.11$ and -0.92 percent) in regions two and three.
Pro-poor curves have been calculated and their behavior are shown in Figure 2 and $\mathbf{3}$ for the country using the type $R$-pro-poor approach. From expression (2) it can be seen how the quintiles 1, 2 and 3 have evolved pro-poor with a first order condition $(s=1)$, that is, 2014 shows to be the year where the fiscal system 

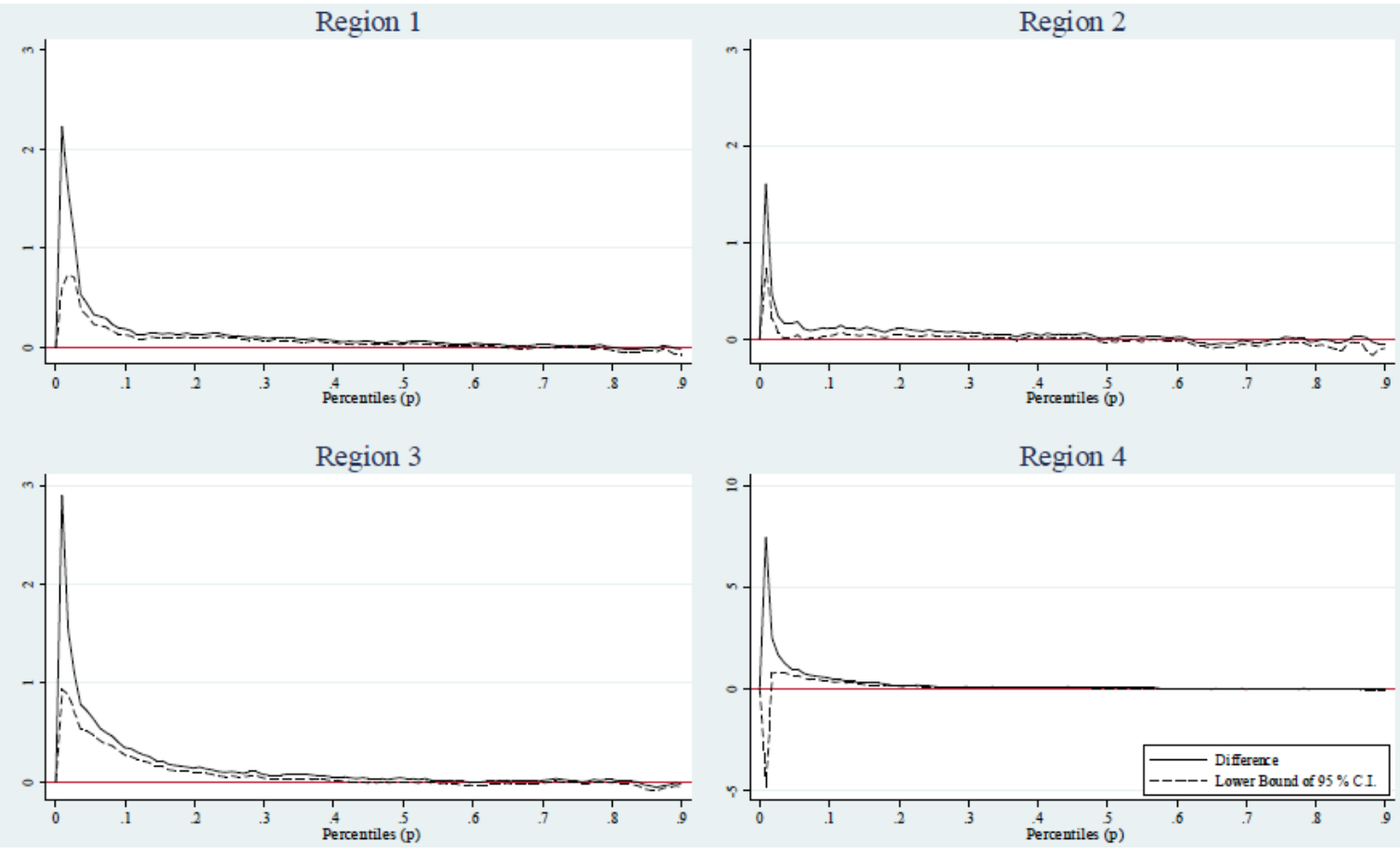

Figure 4: First order relative propoor curves in Mexican Regions: 2002. Dual approach: (Q_2(p)/Q_1(p) - mu_2/mu_1). Source: Author's elaboration using ENIGH.

acted with the greatest effect through taxes and benefits.

It can be used statistical robustness to analyze if growth has been pro-poor. If we use equation (4) moving to a second order condition $(s=2)$, it can be assured in Figure 3 that the fiscal system in 2014 is robustly the year with the highest rate $g$ induced for the quintiles 1,2 and 3, where the lower bound of 95 percent of confidence remain above the null horizontal line.

Regardless of the value taking the order $s$, the trend of $g$ on the percentiles given the tax-benefit system for each year, and according to corollary 1 with condition 2 we can proof that the share increased for the lowest percentiles $(Q(0.3))$ in Mexico. In comparison with GDP growth, cumulative incomes for $s=2$ were higher than GDP growth for each year, respectively (see Figure $\mathbf{3}$ and Table $\mathbf{1}$ ). This result is explained by the condition $d\left(t_{i j}-b_{i j}\right)<0$, which implies that benefits had more incidence than taxes for these quintiles in the distribution.

From Figure $\mathbf{4}$ and first order condition $(s=1)$ it can be inferred for the Mexican regions the pro-poorness process in the year 2002. Region three presented the highest effect on income growth on $g$ with a maximum level of 3 percent for the very lowest quintile, while for the country this region registered a negative GDP growth in the same year $(-0.613)$. Also in Figure 4, for regions one and two a robust first order pro-poor process is found with a rate $g$ of 2.2 percent and 1.6, while the value of $g$ in region four cannot be considered as pro-poor.

If we move to a second order condition to search for robustness Figure $\mathbf{5}$ displays that in region one a propoor process is found, where the lowest three quintiles registered 0.501 percent, though, this level is not greater than economic growth of 0.817 in that year, while in the graph it can be checked how the lowest percentile registered an increase of about 2.5 percent on mean incomes within its group, that is, greater than GDP growth. For regions three and four nothing can be said about pro-poorness.

Although $R$-pro-poorness is observed, the growth in equivalent income is insufficient compared to GDP growth. Reviewing the pro-poor growth for 2008 in Figure 6, results were not statistical robust for regions two and three; regions one and four were robustly first order $R$-pro-poor but with $g$ values below to GDP growth (see Table 1). In both regions, only the average cumulative income growth of the quintiles 1,2 and 3 shown in Figure 7 denoted a greater $g$ values (1.57 and 2.73, respectively) with respect to regional GDP growth (1.07 and 1.09 for each region). Notice that for 

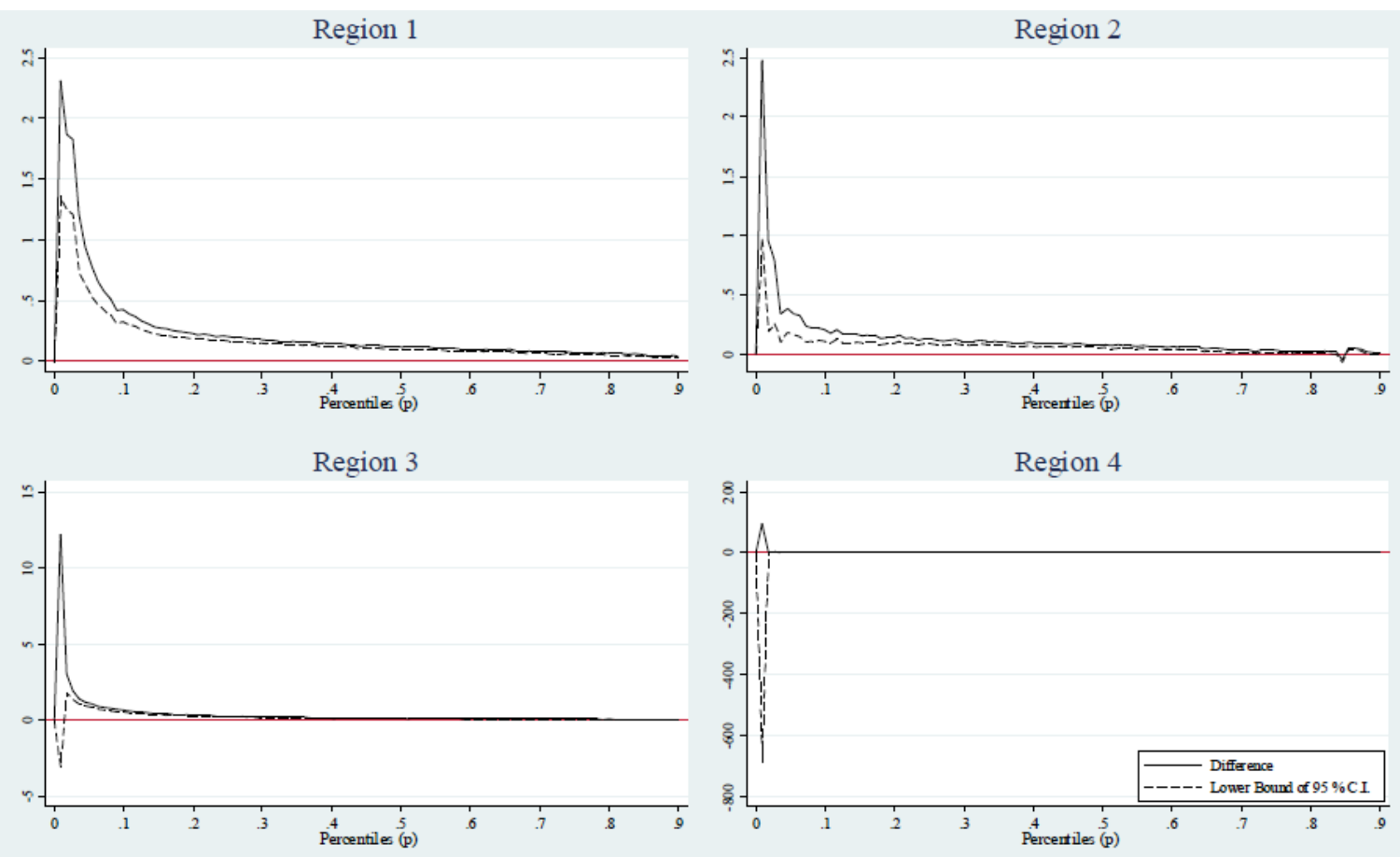

Figure 5: Second order relative propoor curves in Mexican Regions: 2002. Dual approach: $\left(L_{-} 2(p) / G L \_1(p)-m u \_2 / m u \_1\right)$. Source: Author's elaboration using ENIGH.
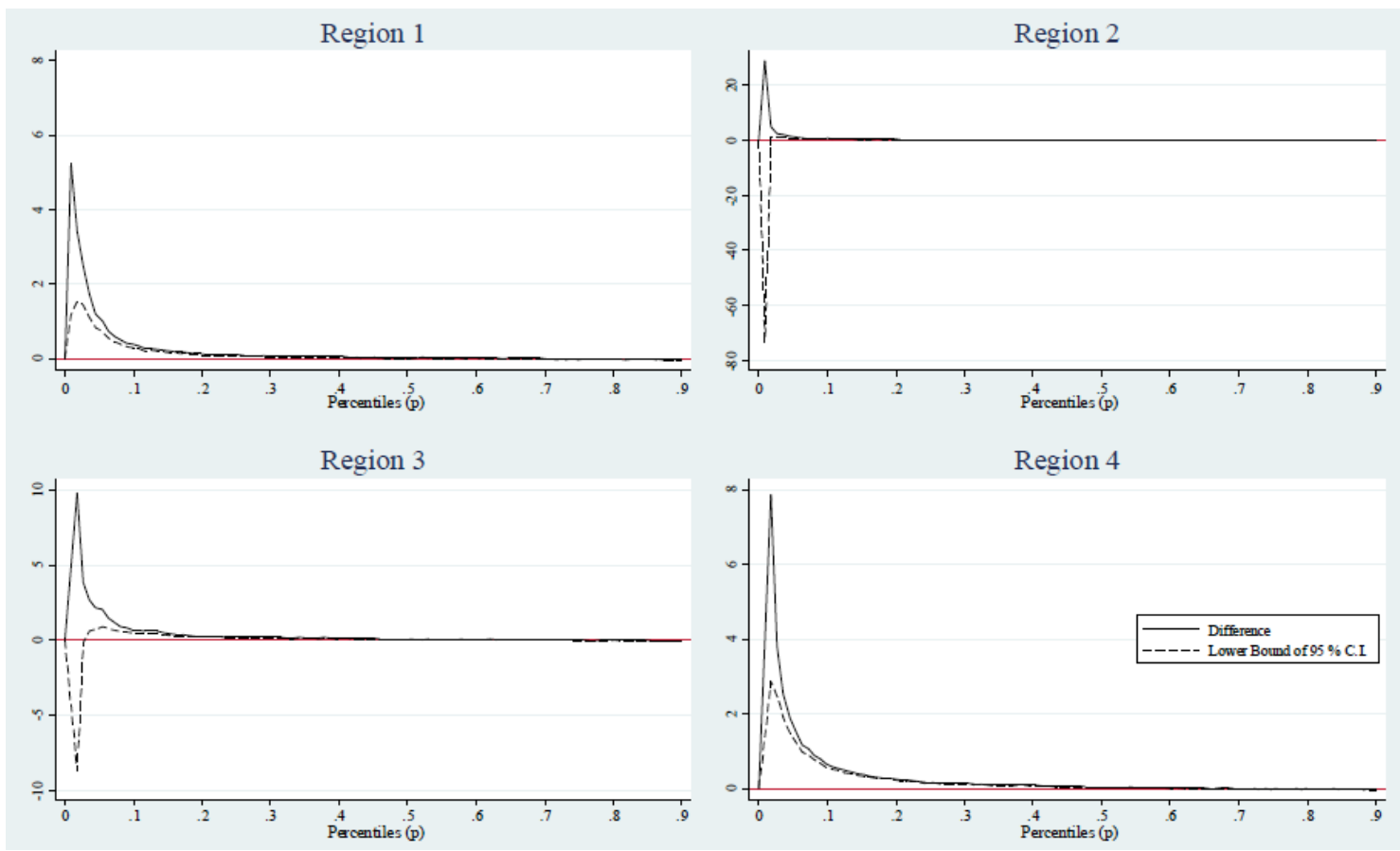

Figure 6: First order relative propoor curves in Mexican Regions: 2008. Dual approach: (Q_2(p) /Q_1(p) - mu_2/mu_1). Source: Author's elaboration using ENIGH.

region one, a second order R-pro-poorness was observed even though its lower bound crossed slightly under the null horizontal line.

Concerning regional estimates for 2014 , only region four was first order $R$-pro-poor (see Figure 8) in a greater rate than regional GDP growth (see Table 1). In contrast, according to second order curves estimated in equation (4) regions two, three and four were $R$-propoor; in which region three presented a greater cumulative equivalent income growth for quintiles 1, 2 

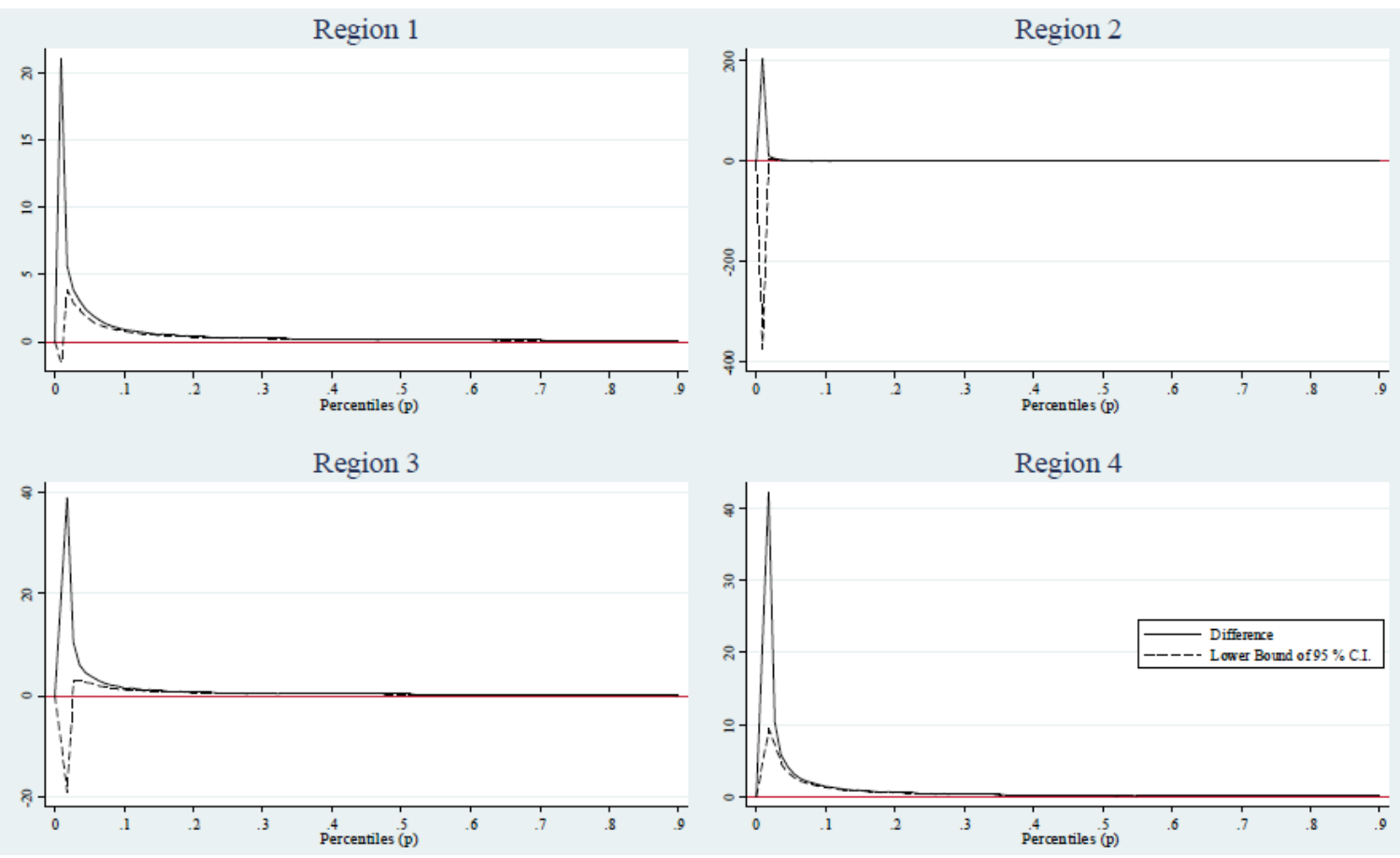

Figure 7: Second order relative propoor curves in Mexican Regions: 2008. Dual approach: $\left(L_{-} 2(p) / G L \_1(p)-m u \_2 / m u \_1\right)$. Source: Author's elaboration using ENIGH.
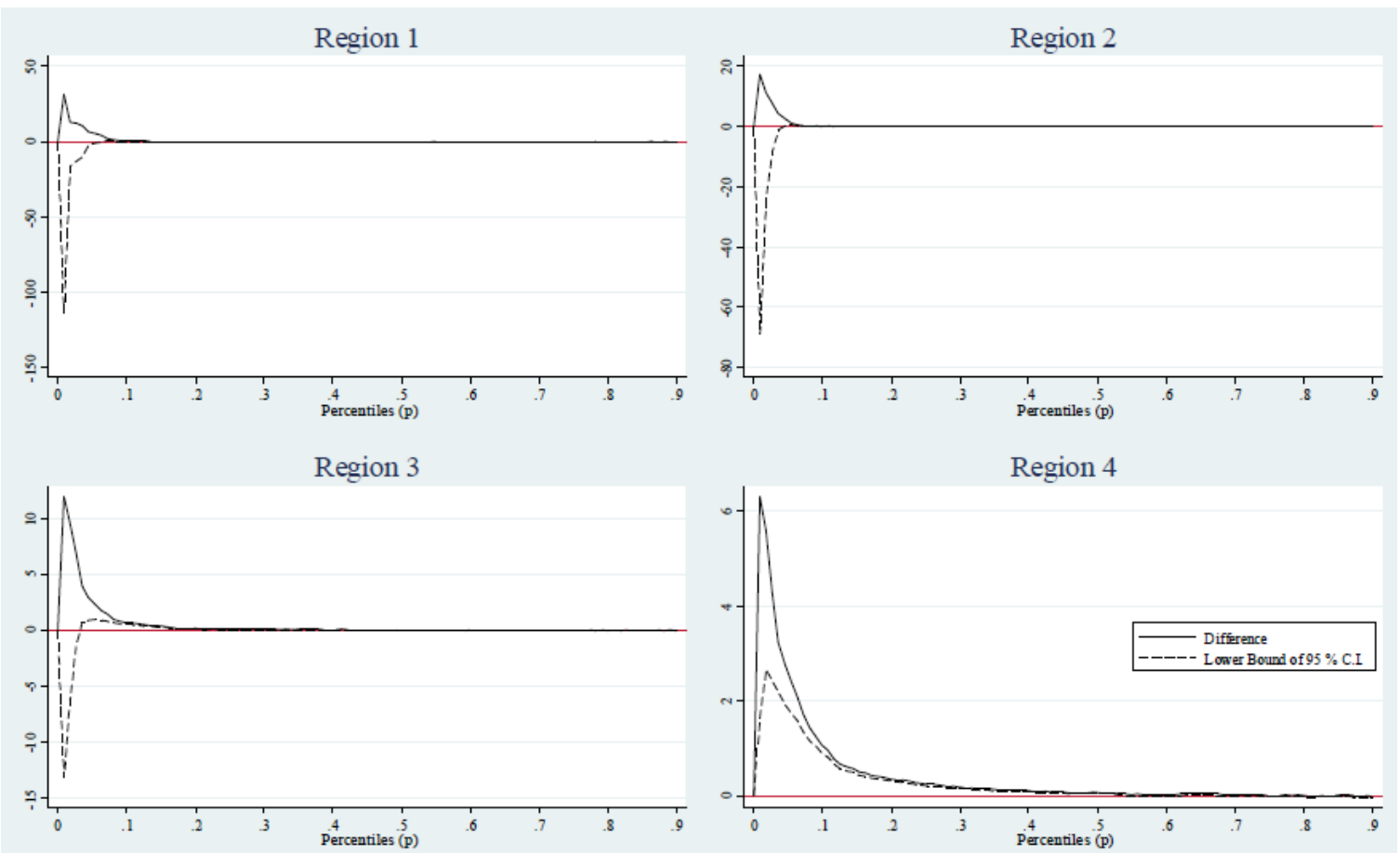

Figure 8: First order relative propoor curves in Mexican Regions: 2014. Dual approach: (Q_2(p) /Q_1(p) - mu_2/mu_1). Source: Author's elaboration using ENIGH.

and 3 (Figure 9 and Table 1). This results give insights of a good performance of the tax-benefit system in region four as long as the transfer incidence were higher than taxes for the lowest quintiles $\left(d\left(t_{i j}-b_{i j}\right)<0\right)$. On the contrary, pro-poorness conclusion cannot be confirmed from region one due to the lack of statistical robustness.

Our empirical evidence is comparable with those results from Araar (2012) for five Andean countries and 


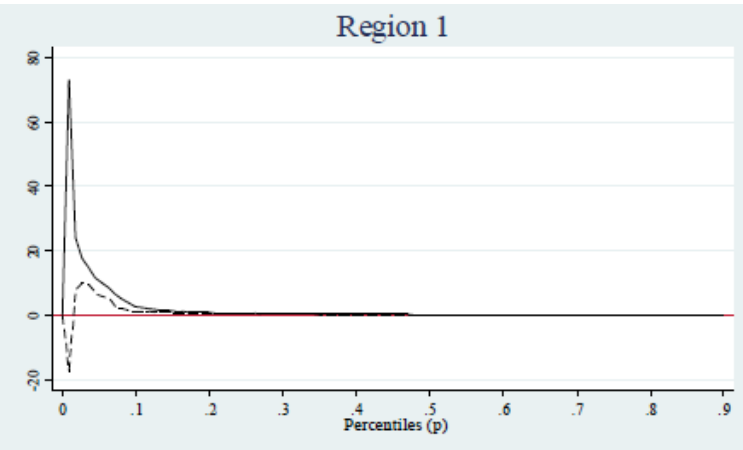

Region 3

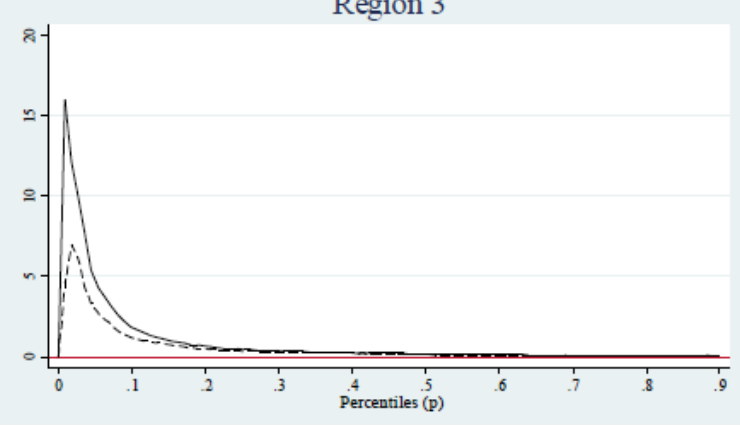

Region 2

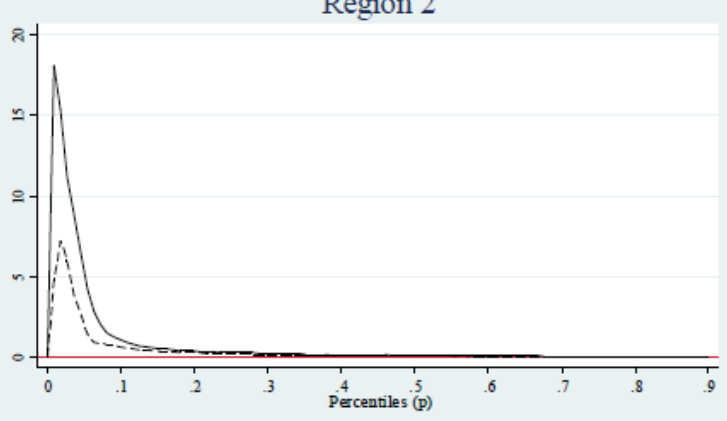

Region 4

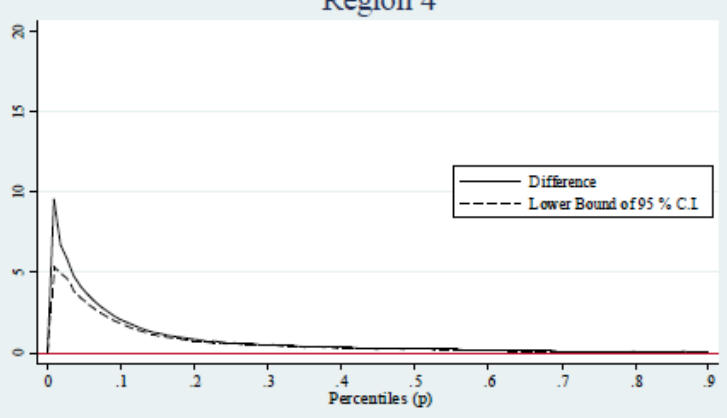

Figure 9: Second order relative propoor curves in Mexican Regions: 2014. Dual approach: $\left(L_{-} 2(p) / G L \_1(p)-m u \_2 / m u \_1\right)$. Source: Author's elaboration using ENIGH.

using the same dual $R$-pro-poor approach. Although Araar (2012) does not reproduced his analysis through a tax system itself, it can be seen for net incomes in Peru, that recent per capita growth has been pro-poor in both absolute and relative terms, though this economy has grown at a slow pace. Prior to 2005 this method is able to determine a period of anti-poor economic growth in Peru, without the need to require checking improvements in favor of the poor.

On the other hand, Ecuador shows R-pro-poor growth before 2008 and afterwards the American crisis 2009/2010 as well. For the Bolivian case, growth has been both, $A$-pro-poor and $R$-pro-poor but just for the lowest incomes and for a sustained and longer period of time 2005/2010. Compared to Bolivia and Ecuador, Mexican case is in line where the lowest percentiles presented and improvement of incomes and higher than GDP growth using $s=2$ for all the years. The regions number two and three registered in 2008 a positive pro-poorness effect on $g$ values compared to regional GDP growth. Lastly, only region three presented for $s=2$ this tendency in 2014, not just for the quintiles $1^{\text {st }}, 2^{\text {nd }}$ and $3^{\text {rd }}$ but also for all the distribution (Figure 9).

In Colombia the rate of growth was 5 percent during 2004 and 2010, but using microdata growth was 4.1 percent, which end up with decreasing poverty levels by about 10 percent (Araar, 2012:30). Also, Colombian inequality is similar than in Mexico with levels of 0.53 . An interesting comparison is that first order $R$-pro-poor was proved in the period of economic crisis $(2008 / 09)$ as well as in the period $(2005 / 10)$ as a whole.

\section{CONCLUSION}

This research has the task of being able to determine for three years $(2002,2008$ and 2014) if the growth on pre-fiscal and post-fiscal incomes has been pro-poor, in relative terms with the dual R-approach. Also, we analyze if whether the regions presents a better pro-poor condition than for the country. It was found that the fiscal system for every year has a nil impact on income growth for the entire distribution; however, for the lowest percentile $\left(1^{\text {st }}\right)$ the net tax balance acted in favor of the really poor with higher income growth.

Considering statistical robustness, findings show a Mexican fiscal system to be weakly $R$-pro-poor for 2002, 2008 and 2014, however for the regional level it can be found important differences. Mexican economy grew at a slow pace in this period with values of 0.38 , 0.76 and 0.45 percent. Then, we summarize our findings as follows:

- $\quad$ The fiscal system tends to be more pro-poor for every year, with the greatest effect in 2014 and 
$s=1$ in region number four and in the country as well.

- Despite that fiscal system induced a pro-poor effect on both, the country and its regions, a strong pro-poor effect is observed only for the lowest incomes and for some regions such as region number four.

- Region number four tends to incorporate a greater number of Mexican states throughout the period. This implies that increase on economic growth does not induce an improvement on wellbeing for the entire population (poverty increased as well).

- With respect to 2008, even though economic growth was higher than $g$ values for $s=1$ in regions number one and four (1.16 and 1.95 percent), the pro-poorness effect from the taxbenefit system diminished.
- Regions number one and four in 2008 and region number four in 2014 presented a positive quality of pro-poorness effect and beyond the economic growth in the economy.

- Horizontal inequity from the fiscal system is an important issue on the regions where those registering $g$ values below than GDP growth, presents a low tax-burden and low incidence of benefits in the population.

The Mexican fiscal system has a nil impact over the entire population in order to decrease horizontal inequity. A recommendation would be to strengthen fiscal compliance and add more tax-payers to contribute for the tax-burden to make benefits stronger. Since the Mexican fiscal system is pro-poor, this will help to reinforce a greater impact from the programs of benefits targeted to the lowest incomes. This process will produce an increase on wellbeing of population without affecting vertical equity of the fiscal system.

\section{APPENDIX 1: MICRODATA FOR MEXICO AND CONSTRUCTION OF THE FISCAL SYSTEM}

Table A1: Tax and Benefit System in Mexico

\begin{tabular}{|c|c|}
\hline \multicolumn{2}{|c|}{ Taxes and Contributions to Social Programs } \\
\hline $\begin{array}{l}\text { Employer's social } \\
\text { security contributions }\end{array}$ & $\begin{array}{l}\text { - For health insurance } \\
\text { - For pensions } \\
\text { - For housing (public lending to finance a house) }\end{array}$ \\
\hline $\begin{array}{l}\text { Employees social } \\
\text { security contributions }\end{array}$ & $\begin{array}{l}\text { - For health insurance } \\
\text { - For pensions } \\
\text { - For housing (public lending to finance a house) }\end{array}$ \\
\hline \multicolumn{2}{|l|}{ Benefits } \\
\hline Non-means-tested & $\begin{array}{l}\text { - Pensions (Not included in benefits, but included in net income) } \\
\text { - Others transfers (Are transfers from unknown source in the survey) }\end{array}$ \\
\hline
\end{tabular}

Source: Authors' elaboration according to methodology. 
Table A2: Mexican Regions: 2002, 2008 and 2014

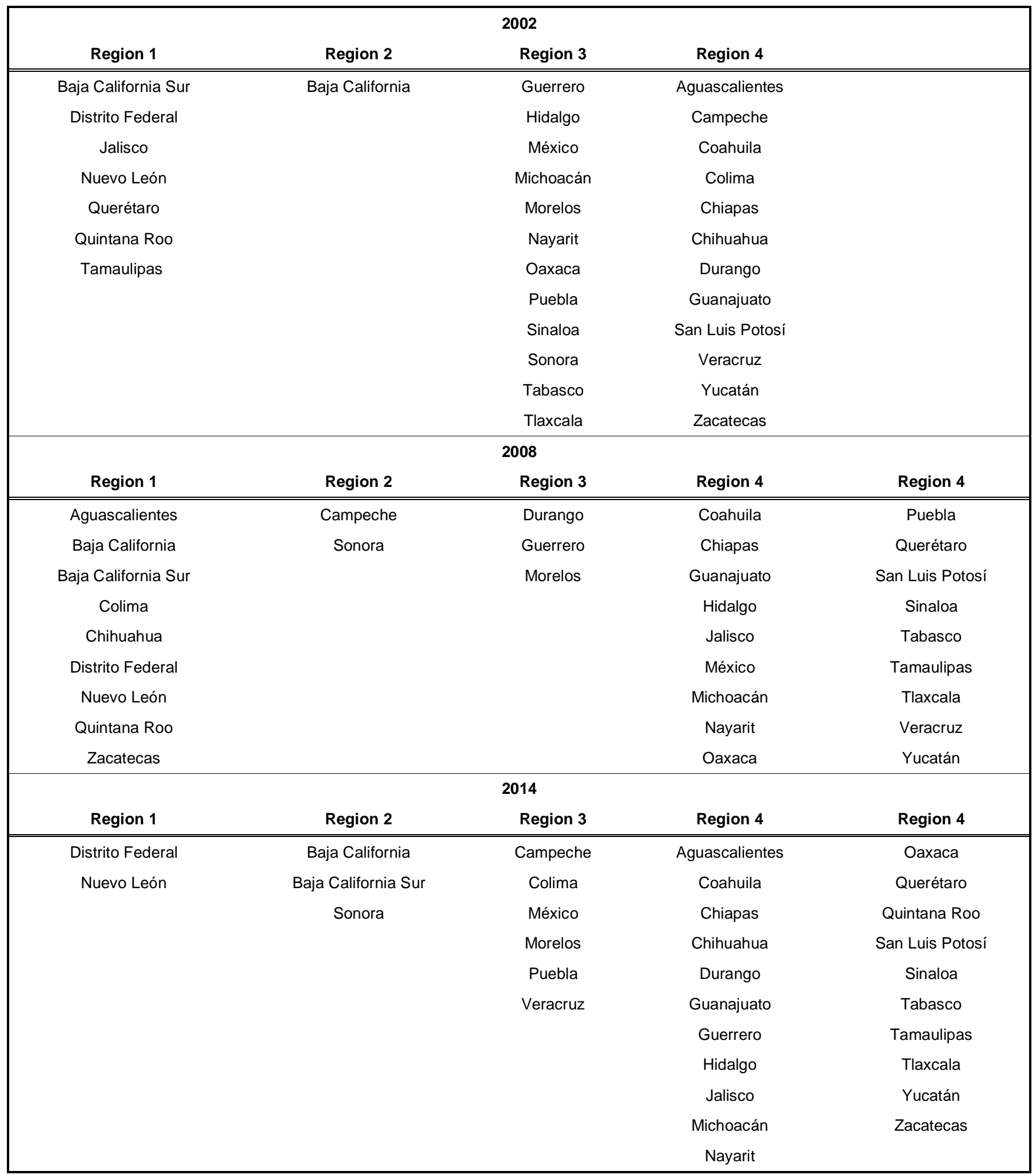

Source: Authors' elaboration according to methodology.

\section{REFERENCES}

Araar, Abdelkrim. 2012. "Pro-poor Growth in Andean Countries." Working Paper 1225, CIRPÉE, Université Laval.
Araar, Abdelkrim and Jean-Yves Duclos. 2013. User manual DASP version 2.3. Distributive Analysis Stata Package, PEP, CIRPÉE and World Bank, Université Laval, June.

Araar, Abdelkrim, Jean-Yves Duclos, Mathieu Audet, and Paul Makdissi. 2009. "Testing For ProPoorness Of Growth, With 
An Application To Mexico". Review of Income and Wealth, 55: 853-881.

http://dx.doi.org/10.1111/j.1475-4991.2009.00357.x

Bibi, Sami and Jean-Yves Duclos. 2010. "A Comparison of The Poverty Impact Of Transfers, Taxes And Market Income Across Five OECD Countries". Bulletin of Economic Research, 62: 387-406. http://dx.doi.org/10.1111/j.1467-8586.2009.00339.x

Bird, Richard. 1995. "Tax Policy: Past, Present, and Future". Canadian Tax Journal, 43(5): 1039-1054.

Bird, Richard and Pierre-Pascal Gendron. 2011. Equity and the Informal Sector. In: The VAT in Developing and Transitional Countries, New York, Cambridge University Press., 2nd reimpression ed.

Buchanan, James M. and Richard A. Musgrave. 2001. "Public Finance and Public Choice: Two Contrasting Visions of the State". Public Choice, 106: 196-199. http://dx.doi.org/10.1023/A:1005271812684

Claus, Iris, Jorge Martinez-Vazquez, and Violeta Vulovic. 2013. "Coping with Rising Inequality in Asia: How Effective Are Fiscal Policies?" Asian Economic Papers, 12: 1-33. http://dx.doi.org/10.1162/ASEP a 00232

CONEVAL. 2015. "Informe de Pobreza Multidimensional en Mexico 2014". Informe de Evaluación 2015:1, CONEVAL.

CONEVAL. 2009. "Informe de Pobreza Multidimensional en Mexico 2008". Informe de Evaluación 2009:1, CONEVAL.

Davidson, Russell and Jean-Yves Duclos. 1997. "Statistical Inference for the Measurement of the Incidence of Taxes and Transfers". Econometrica, 65: 1453-65. http://dx.doi.org/10.2307/2171744

Deaton, Angus. 1998. The Analysis of Household Surveys: A Microeconometric Approach to Development Policy, John Hopkins University Press.

Duclos, Jean-Yves. 2009. "What is Pro-Poor?" Social Choice and Welfare, 32: 37-58. http://dx.doi.org/10.1007/s00355-008-0308-x

Duclos, Jean-Yves and Abdelkrim Araar. 2006. Poverty and Equity Measurement, Policy, and Estimation with DAD, Berlin and Ottawa: Springer and IDRC.
Duclos, Jean-Yves, Paul Makdissi, and Abdelkrim Araar. 2014. "Propoor indirect tax reforms, with an application to Mexico". International Tax and Public Finance, 21: 87-118. http://dx.doi.org/10.1007/s10797-012-9260-x

German-Soto, Vicente. 2005. "Generación del producto interno bruto mexicano por entidad federativa, 1940-1992". El Trimestre Económico, 72(3): 617-653.

German-Soto, Vicente. 2014. Population Statistics by Mexican federal entity. Selected works, Universidad Autónoma de Coahuila. http://works.bepress.com/vicente_german_soto/54/

Huesca, Luis and Abdelkrim Araar. 2016. "Comparison of the Tax System Progressivity Over Time: Theory and Application with Mexican Data". Estudios Económicos, 31(1): 3-45.

INEGI. 2015a. "Encuesta Nacional de Ingresos y Gastos de los Hogares". Microdata various years available at: http://inegi.org.mx, INEGI.

INEGI. 2015b. Database of GDP for Mexican states 2002-2015. Sistema de Cuentas Nacionales.

Kakwani, Nanak and Ernesto M. Pernia. 2000. "What is Pro-poor Growth?" Asian Development Review, 16: 1-22.

Lustig, Nora, Carola Pessino, and John Scott. 2014. "The Impact of Taxes and Social Spending on Inequality and Poverty in Argentina, Bolivia, Brazil, Mexico, Peru, and Uruguay: Introduction to the Special Issue". Public Finance Review, 42: 287-303. http://dx.doi.org/10.1177/1091142113506931

Musgrave, Richard. 1990. "Horizontal Equity, Once More". National Tax Journal, 43: 113- 122.

Pechman, Joseph A., and Benjamin A. Okner. 1974. Who Bears the Tax Burden? Brookings Institution, Washington.

Scott, John. 2014. "Redistributive Impact and Efficiency of Mexico's Fiscal System". Public Finance Review, 42: 368-390. http://dx.doi.org/10.1177/1091142113497394

Teruel, Graciela, Luis Rubalcava, and Alicia Santana. 2005. Escalas de Equivalencia para México, Secretaría de Desarrollo Social-Serie Documentos de Investigación.

Wagstaff, Adam and Eddy Van Doorslaer. 2001. "What Makes the Personal Income Tax Progressive? A Comparative Analysis for Fifteen OECD Countries". International Tax and Public Finance, 8: 299-316.

Received on 08-03-2016

Accepted on 05-04-2016

Published on 06-05-2016

DOI: http://dx.doi.org/10.6000/1929-7092.2016.05.09

(c) 2016 Huesca and Llamas; Licensee Lifescience Global.

This is an open access article licensed under the terms of the Creative Commons Attribution Non-Commercial License (http://creativecommons.org/licenses/by-nc/3.0/) which permits unrestricted, non-commercial use, distribution and reproduction in any medium, provided the work is properly cited. 